\title{
O Canto do Pássaro Encantado: a religião como saudade em Rubem Alves
}

\author{
Gustavo Claudiano Martins* \\ Edson Fernando de Almeida** \\ Uma canção que se canta. Das antigas. Tem de ser das antigas. \\ Para convocar a saudade. É a saudade que traz para dentro \\ da sala a cena que aconteceu longe. Sem saudade o milagre não acontece. \\ - Alves, 2013, p. 81 \\ O Pássaro Encantado já estava velho. \\ Em sua vida longa voara por todas as partes do mundo. \\ Voava para sentir saudades porque sabia que é na saudade que o amor cresce. \\ Alves apud Gonçalo Júnior, 2015, p. 429
}

\section{Resumo}

Este texto busca entender as variações da expressão "saudade" em Rubem Alves, sobretudo quando essas se correferem à religião. Ainda que não pretenda ser uma análise minuciosa de toda a obra do autor, revela-se que a palavra saudade possui valor singular ao longo de sua trajetória, desde seus primeiros escritos teológicos à fase crepuscular de sua caminhada, marcada mormente por crônicas e histórias infantis. Propõe-se demonstrar os diversos autores que alimentam as ideias de Rubem na construção de sua teoria

* Universidade Federal de Juiz de Fora. Doutorando em Ciência da Religião pela Universidade Federal de Juiz de Fora (bolsista CAPES), mestre em Ciência da Religião pela Universidade Federal de Juiz de Fora/MG (bolsista CAPES), Bacharel em Teologia. Membro do grupo de pesquisa CEPRES - Centro de Estudos Políticos, Religião e Sociedade da Universidade Federal do Amapá e do NEPROTES - Núcleo de Estudos em Protestantismos e Teologias. gcmartins@hotmail.com .

** Doutor em Teologia pela Pontifícia Universidade Católica do Rio de Janeiro, mestre em Teologia pela Pontifícia Universidade Católica do Rio de Janeiro, possui graduação em graduação em Teologia pelo Seminário Presbiteriano do Sul e em Psicologia pela Pontifícia Universidade Católica do Rio de Janeiro (1993). Membro do grupo Apophatiké - Estudos Transdiciplinares em Mistica (UFF/CNPq) e de Mística Comparada (UFJF-CNPq). edsonfernandodealmeida@gmail.com . 
da religião, reiteradamente descrita de forma sensível e poética, mesmo nas composições que aparentemente não se referiam a indagações a respeito do sagrado. O teólogo da Boa Esperança, como também foi chamado, parte da consciência de uma ausência à recriação, por meio da imaginação, dos objetos de nostalgia, para tornar presente o desiderato humano. A saudade, especialmente a "saudade ontológica", é para Rubem a habitação dos sonhos do homem, é ela que fecunda a natureza, engravidando-a de um novo futuro para a humanidade.

Palavras-chave: Rubem Alves. Saudade. Ausência. Teoria da religião. Presença da ausência. Teopoética.

\title{
The Song of The Enchanted Bird: Religion as "Saudade" in Rubem Alves Work
}

\begin{abstract}
The present article aims to understand the variations of the expression "saudade" in Rubem Alves's work, mainly when those variations refer to religion. Although I do not intend to present a minutious analyzis of Alves entire work, it is clear that the word "saudade" has a singular value along his trajectory, from his first theological writings to his twilight phase, which was marked by chronicles and stories for children. My proposal is to demonstrate the variety of authors who fed Alves's ideas and who somehow contributed to his theory of religion, which was constructed in a sensitive and poetic way, even in works which apparently did not refer to questions concerning to the sacred. "The Good Hope theologian", as he was also known, starts from the consciousness of a sort of existential absence towards a certain recriation of nostalgic objects through the imagination. His goal is to make the human desire present. In summary, the "saudade", specially the "onthologic saudade", is for Rubem Alves the home for the men kind dreams - a feeling which is responsible for constantly generating new perspectives for humanity.
\end{abstract}

Key-words: Rubem Alves. Saudade. Absence. Theory of religion. Presence of absence. Theopoetics.

\section{El Canto del Pájaro Encantado: La Religión como "Saudade" en el Trabajo de Rubem Alves}

\section{Resumen}

El presente artículo pretende comprender las variaciones de la expresión "saudade" en la obra de Rubem Alves, principalmente cuando dichas variaciones se refieren a la religión. Aunque no pretendo presentar un detallado análisis de toda su obra, está claro que la palabra "saudade" tiene un valor singular a lo largo de la trayectoria del autor, desde sus primeros escritos teológicos hasta su fase crepuscular, marcada por crónicas y cuentos infantiles. Mi propuesta es demostrar la variedad de autores que alimentaron las ideas de Alves y que, de algún modo, contribuyeron a su teoría de la religión, la cual se construyó de una manera sensible y poética, incluso en obras que aparentemente no se refieren a cuestiones relativas a lo sagrado. "El teólogo de la Buena Esperanza”, como también es conocido, hacia una cierta recriación de objetos nostálgicos a 
través de la imaginación. Su meta es hacer presente el deseo humano. En resumen, la "saudade", especialmente la "saudade ontológica", es para Rubem Alves la casa de los sueños humanos: un sentimiento que es responsable de generar constantemente nuevas perspectivas para la humanidad.

Palabras clave: Rubem Alves. Saudade. Ausencia. Teoría de las religiones. Presencia de la ausencia. Teopoetica.

\section{Introdução}

Longe de casa, Rubem entendeu que a saudade é mais uma variante do espaço do que do tempo, quando, em 1963, deixou o Brasil para cursar o mestrado nos EUA. Nesse período, confessou ele: "era tarde comum, na cidade de Nova Iorque. Fim de ano de sofrimentos. Tinha deixado esposa e filhos no Brasil para fazer um mestrado. Arrumei minhas malas várias vezes para voltar, convencido de que nenhum grau acadêmico valia a dor da separação" (ALVES, 2012, p. 30). Em certo momento, segundo relata Gonçalo Júnior (2015, p. 308) na biografia que escreve a respeito do teólogo de Boa Esperança, Rubem dissera: "a saudade entrou tanto dentro de mim que sinto vontade de vomitar. Gozado como os sentimentos entram no corpo". Silva (2014, p. 85), poeticamente, escreve que Rubem deixou sua mulher e dois filhos para morar com a saudade. Entrementes, nos parece que descobrira que a saudade mora no homem.

Posteriormente, sofreu ao se ausentar da pequena filha Raquel a fim de ministrar palestras pelo mundo e, no crepúsculo da vida, sofreu pela dor da separação de um grande amor, sua segunda esposa. Talvez por isso a palavra tornou-se tão cara na linguagem de Alves. Tema de muitos dos seus livros infantis e recorrente em suas crônicas, a saudade já era mote das conversas com seu amigo norte-americano Wayne, para quem ensinou o sentido da palavra inexistente no idioma inglês, dotada de sentido tão profundo, "saudades é onde Deus mora, na presença de uma ausência. O amor mora nas presenças das ausências" (GONÇALO JÚNIOR, 2015, p. 248). Assim, não é difícil encontrar, ainda nas reflexões sobre religião, proposições acerca desse objeto. Antes, é preciso ter em mente que Alves se aproxima de Feuerbach $(2013$, p. 50, 44) para quem, dizer "Deus" significa dizer "a religião", com ressalvas de que não se trata na crença de um ser sobrenatural, todavia, como a "revelação solene das preciosidades ocultas do homem, a confissão dos seus mais íntimos pensamentos, a manifestação pública dos seus segredos de amor".

Foi o próprio Rubem quem disse que as analogias são a melhor forma de explicar coisas aparentemente complexas. "O uso das analogias é um dos artifícios mais fantásticos para ensinar. Quando você usa uma boa metáfora, 
a pessoa entende na mesma hora. Os conceitos têm a função de dar precisão ao detalhe, mas a analogia e a metáfora dão a visão das coisas" (ALVES apud NUNES, 2014, p. 226).

\section{Fenomenologia da saudade}

Segundo Antunes (1983, p. 27), a palavra saudade tem por étimo o adjetivo e advérbio latino solu, ou seja, nela flui a ideia de "estar só" em dois sentidos possíveis, de estar só no espaço físico (solidão - solitas) e estar só na esfera psicológica (solitude - solitudo; soledade - solitudine). Essas variações produziram as palavras soedade, suidade e soidade, portadoras do "estar só". Entretanto, como explicar a variação "s-au-dade"? Isso se deu a partir do influxo, por analogia e associação, aos vocábulos da raíz saud, de onde vem o verbo saudar e os substantivos saúde e salvação (conforme utilizado na Bíblia). Assim, semanticamente é possível explicar a aproximação associativa entre os sentimentos "estar só", "estar distante", "estar ausente" e "estar doente", às ideias de "saúde", "saudação" e "salvação". Para isso, o autor chama a atenção à prática corrente na correspondência epistolar:

...onde os termos "saúde", "saudades" e "saudações" são quase religiosamente usadas, numa alternância indistinta. Tão natural é enviar "saudações a todos", como "saudades a todos". Ora, nós sabemos que o gesto de saudar é algo que naturalmente ocorre no primeiro contato com o ente da relação. No caso epistolar, celebra-se o "encontro" à distância com "votos de boa saúde", isto é, augura-se ao amigo, ou ente querido ausente, um estado de saidade (de sanitate) de que, de certa forma está privado, no momento presente, devido à condição de separado ou ausente. Só depois é que ocorre a situação da despedida, a qual por sua vez, envolve outra tônica saudosa. Esta tônica está implícita na fórmula "saudações", mesmo que, aparente, possa parecer repetição ou redundância.

Não é já a saudade-encontro, como no início; é, antes, a "saudade" (de salutatio) que condensa um vocabulário só - saudade -, as ideias de "saudar" e "votos de salvação". Salvação de que maneira? Pelo reencontro físico, o antes possível; quando, então, a alma de ambos ficará sã, isto é, encontrar saidade. "Dessas tais fórmulas convencionais, - conclui Carolina Michaëlis - e de outras semelhantes, milhares de vezes repetidas, isto é: da saudade, das saudações, e das suidades à antiga (e talvez de desejos de saudade-salutate enviadas e tornadas) é que, a meu ver, saíram as saudades modernas em que há parte de tudo isso: da saúde desejada aos ausentes, das saudações com eles trocadas; 
da sensação de soedade/soidade/suidade provocada pelo afastamento, e do desejo da única salvação possível (ANTUNES, 1983, p. 29, 30).

Para além disso, Antunes (1983, p. 212) no belíssimo livro Saudade e Profetismo em Fernando Pessoa, afirma que o poeta português deu corpo à saudade, emanando sobretudo de seu desencanto do presente e "suas manifestações de modo concreto quer como saudade do passado: a infância, as origens, a terra, quer como saudade do futuro: carência metafisica, religiosa e de significação político-messiânica; quer finalmente, como realidade atemporal: a saudade de si mesmo nas múltiplas formas de distanciamento psicológico". Se em Pessoa observa-se o desgosto para com tudo, não se pode dizer o mesmo de Rubem, seus textos revelam o amor pelos prazeres da vida e em especial em sua fase crepuscular, vê-se certo descontentamento com a aproximação da morte.

De um lado, a saudade do passado é manifesta em suas crônicas, histórias infantis e nas inúmeras palestras que ministrava, de outro lado, a saudade do futuro e também a atemporal, eram marcas essenciais em seus textos sobre religião, aliás, assim como Pessoa, Rubem creditava ao descontentamento com a realidade o manancial da religião no ser humano. ${ }^{1}$ Destarte, é sobre essa dimensão saudosa do pastor poeta que se discorre a seguir. "Saudade que, forçosamente, idealiza a distância para compensar o desencanto imediato" (ANTUNES, 1983, p. 216).

\section{Instinto incompleto: consciência de uma ausência}

O poeta português, sob o "semi-heterônimo" Bernardo Soares (1988) no fragmento 22 do Livro do Desassossego, exprimiu: "Deus é o existirmos e isto não ser tudo". Deus é o germe do embate entre essência e existência, entre a realidade empírica e a realidade ideal. Segundo Pessoa, é essa idiossincrasia que nos distingue dos animais, afinal:

...não é fácil distinguir o homem dos animais, não há critério seguro para distinguir o homem dos animais. As vidas humanas decorrem na mesma íntima inconsciência que as vidas dos animais. As mesmas leis profundas, que

\footnotetext{
Rubem Alves (1984a, p. 44, 45) assim descreve esse descontentamento humano: Nas palavras de Camus, "o homem é a única criatura que se recusa a ser o que é"; "com a rebelião nasce a consciência". Ou, nas palavras de E. Bloch, para o homem "o que é não pode ser verdade". O dualismo, ou mais precisamente a dialética, divide assim o mundo entre o que é (a realidade objetiva) e o que deve ser (o ético), aquilo que é dado objetivamente como fato e as exigências antropológicas do homem que vive e sofre esses fatos e se organiza para a sua separação. Tal conflito revela uma tensão entre a existência (o que é) e uma exigência ética de superação (a essência). Segue-se a conclusão inevitável: "para o homem o absoluto não é dado, mas a sua própria essência. O homem é o seu próprio Deus”.
} 
regem de fora os instintos dos animais, regem, também, de fora, a inteligência do homem, que parece não ser mais que um instinto em formação, tão inconsciente como todo instinto, menos perfeito porque ainda não formado (PESSOA, 1988, fragmento 149).

Somos movidos por esse instinto incompleto. De algum modo, somos dotados de devaneios, derivados de uma programação biológica inacabada. É assim também que Rubem Alves (1981, p. 16) nos diferencia dos animais, “a aventura da liberdade não lhes é oferecida, mas não recebem, em contrapartida, a maldição da neurose e o terror da angústia", e continua para tentar desvendar esse mistério antropológico:

Os animais sobrevivem pela adaptação física ao mundo. Os homens, ao contrário parecem ser constitucionalmente desadaptados ao mundo, tal como ele lhes é dado. Nossa tradição filosófica fez seus sérios esforços no sentido de demonstrar que o homem é um ser racional, ser de pensamento. Mas as produções culturais que saem de suas mãos sugerem, ao contrário, que o homem é um ser de desejo. Desejo é sintoma de privação de ausência. Não se tem saudade da bem-amada presente. A saudade só aparecerá na distância, quando estiver longe do carinho. Também não se tem fome - desejo supremo de sobrevivência física - com o estômago cheio. A fome só surge quando o corpo é privado de pão. Ela é testemunho da ausência do alimento. E assim é, sempre, com o desejo. Desejo pertence aos seres que se sentem privados, que não encontraram prazer naquilo que o espaço e o tempo presente lhes oferecem. [...] Canções fúnebres exorcizarão a morte? Parece que não. Mas elas exorcizam o terror e lançam pelos espaços afora o gemido de protestos e a reticência de esperança. E os poemas do cativeiro não quebram correntes e nem abrem as portas, mas, por razões que não entendemos bem, parece que os homens se alimentam deles e, no fio tênue da fala que os enuncia, surge de novo do protesto e o brilho da esperança. [...] As esperanças do ato pelo qual os homens criaram a cultura, presentes no seu próprio fracasso, são horizontes que nos indicam direções. E esta é a razão por que não podemos entender uma cultura quando nos detemos na contemplação dos seus triunfos técnicos/práticos. Porque é justamente no ponto que ele fracassou que brota o símbolo, testemunha das coisas ausentes, saudade de coisas que não nasceram (ALVES, 1981, p. 19-22). 
Deveríamos repetir aqui a pergunta da canção: "você tem fome de quê?", ${ }^{2}$ o homem tem fome de quê? Sentido de vida, esse pão que alimenta a alma e torna possível a existência. Sentido que não é um objeto, mas uma relação. Assim como a saudade é o hífen que aproxima dois corpos separados (Eu-Tu), ${ }^{3}$ a religião é o símbolo entre o sujeito e o sentido da vida. Dessa forma, a religião se manifesta como saudade, como saudade ontológica.

Doravante, Rubem avança quanto às antigas questiúnculas entre explicações substancialistas e funcionalistas da religião, apostando no ser como relação ${ }^{4}$ e, consequentemente, a religião como subproduto correlacional da ausência de um fundamento, e da inversa fundamentação justamente na ausência. Para isso, leva em consideração autores como Nietzsche, Schopenhauer e Heidegger que fundam outra metafísica, definida por Bogéa (2016, p. 26) como "Metafísica do Impossível", assim descrevendo:

Levada às últimas consequências, a metafísica da vontade pode configurar uma "Outra Metafísica" que, para nós, poderia ser bem nomeada como uma "Metafísica do Impossível", de vez que para "além" do mundo, vigente como fundo sem fundo do mundo, como abismo fundante do mundo, como presença da ausência e ausência da presença, resta sempre a marca indelével do Impossível, que, um pouco como o "nada" heideggeriano, não se deixa eliminar por uma caracterização meramente negativa - e que assim como o Ser heideggeriano, não se deixa capturar por alguma caracterização meramente positiva. Metafísica do Impossível diz: o "além" é realmente impossível, mas o Impossível está realmente "além", fundando e fundamentando mundo - qualquer mundo possível - no sem-fundo abissal da impossibilidade de fundamentação.

2 Cf. música: Comida (Titãs).

3 Essas ideias são bem descritas por Feuerbach (2013, p. 105), quando diz que "a primeira pedra de choque contra a qual se choca o orgulho do Eu é o Tu, o outro Eu. Primeiramente reforça o Eu a sua vista no olhar de um Tu, antes de suportar a contemplação de um ser que não lhe reflita a sua própria imagem. O outro homem é aponte entre mim e o universo, porque inicialmente me sinto como dependente de outros homens. Se não necessitasse do homem, não necessitaria também do universo. Eu me concilio, me torno amigo do universo somente através do ouro homem. Sem o outro o universo não só seria para mim morto e vazio, mas também sem sentido e sem razão".

4 Rubem Alves chega a dizer que "Vida é relação", o mundo se constitui a partir da maneira pela qual o homem se relaciona com aquilo que o circunda. Parte de autores como Martin Buber, Heidegger e o já citado Feuerbach (Cf. ALVES, 1984a). 
Todavia, se para Schopenhauer (2001) o axioma fundamental se encontra na vontade como experiência primordial vivenciada de forma imediata pelo corpo, Rubem afirma que vontade/desejo procede a ausência, i.e., é sintoma de privação. Ora, se para o primeiro a essência do indivíduo é aquilo que chamamos de vontade, ${ }^{5}$ para Rubem, sua essência ${ }^{6}$ é uma ausência, ou ausências.

Segundo Bogéa (2016, p. 44), para Schopenhauer “...a vontade, a essência do mundo, não é, nem pode ser compreensível ou explicável pelo entendimento ou pela razão. A vontade é por si mesma grundlos, sem fundamento", 7 o mesmo se dá com Rubem ao longo dos seus textos, em especial quando faz diferenciação entre saber e sabor, ${ }^{8}$ ou quando se debruça sobre o conceito de "verdade". Podendo, portanto, ser incluído na longa lista de "irracionalistas", como os já citados Schopenhauer, Nietzsche e Heidegger, também Freud, Deleuze e Derrida. Assim, Rubem ao formular sua teoria a respeito do Ser, rechaça a redução do ser humano ao cognitivismo, que, segundo Do Valle (apud BOGÉA, 2016, p. 47),

...é o resultado do longo processo de substituição das "filosofias do espírito" tradicionais, de caráter marcadamente moralista, pelo "mentalismo" - que assimila o espírito a um conjunto de processos interiores capazes de definir um sujeito, ou um cogito, e que produzem as significações que ele fornecerá para as coisas exteriores. A rigor, o mentalismo começa com Descartes, para quem a busca das determinações da vida interior configurava a investigação sobre a origem e organização das ideias, ou sobre as representações subjetivas.

5 Cf. Bogéa (2016, p. 42), a "essência, deve ser o mesmo que aquilo que nós chamamos em nós vontade".

6 A questão da "essência humana" defendida por Feuerbach também é discutida por Alves (1984a, p. 43-47). A objeção que se tem contra Feuerbach, é que tal coisa não existe, assim como fez Marx nas Teses sobre Feuerbach "a essência humana não é uma abstração inerente a cada indivíduo. Na sua realidade ela é o conjunto das relações sociais". Todavia, o próprio Rubem lembra que, as semelhanças são grandes entre a ideia de essência de Feuerbach e, por exemplo, o conceito de inconsciente de Freud, e na diferenciação entre o homem e os animais feita por Durkheim. Para além disso, Rubem reconhece que o conceito feuerbachiano de essência tem um "sabor substantivo e a-histórico". Nas considerações e leituras aqui expostas, percebe-se que, se Alves utiliza tal tipo de conceito, certamente, o mesmo não possui caráter a-histórico, com pretensão de determinar o comportamento humano.

7 Esse argumento parece o mesmo utilizado posteriormente por Rudolf Otto (2014) para explicar o "Sagrado", uma "metafísica do irracional" e também por Feuerbach (2013) ao falar sobre os fundamentos da essência humana - razão, vontade e sentimento.

8 Rubem Alves (2011, p. 57-67) escreve um capítulo intitulado "Dos saberes aos sabores", incluso no livro Variações sobre o pražer. Segundo ele "ciência são palavras que dizem um saber. Sapientia sãos as palavras que apontam para um sabor".

9 Em especial, no capítulo "O que significa dizer a verdade" do livro O Suspiro dos Oprimidos (Cf. ALVES, 1984a, p. 145-170). 
Mas deve-se atribuir à progenitura mais direta de Locke a tendência moderna a privilegiar o estudo do "entendimento humano", isso é, a intenção de identificar as leis de funcionamento dos "estados mentais".

Além do biólogo Uexküll, Rubem (1983, p. 157) busca sua fundamentação para a hipótese de que o ser humano é um sujeito da ação e não do conhecimento em autores como Cassirer, Kurt Goldstein, Merleau-Ponty e Feuerbach. Em suma, não se trata de um objeto, mas de uma condição existencial, muito bem descrita no poema "Ausência" de Drummond..$^{10}$

Por muito tempo achei que a ausência é falta.

E lastimava, ignorante, a falta.

Hoje não a lastimo.

Não há falta na ausência.

A ausência é um estar em mim.

E sinto-a, branca, tão pegada, aconchegada nos meus braços, que rio e danço e invento exclamações alegres, porque a ausência, essa ausência assimilada, ninguém a rouba mais de mim.

A ausência é uma singularidade do corpo. A mesma conclusão alcançada por Bogéa (2016, p. 49, 50) ao analisar Schopenhauer pode ser aplicada a Rubem e toda a sua teoria do conhecimento:

$\mathrm{Na}$ essência não está o Bem, não está a ideia, não está a substância, não está Deus, não está a racionalidade do sujeito pensante, não está a verdade objetiva ou subjetiva do mundo. $\mathrm{Na}$ essência está o movimento volitivo, e com ele a falta irremediável que determina sua insaciedade, na essência está a impossibilidade de satisfação definitiva que mantém o pêndulo eternamente oscilante entre a decepção e o tédio. O conhecimento dessa verdade essencial, a "verdade filosófica por excelência", não se resume ao domínio racional ou cognitivo. Este conhecimento se mostra numa experiência corporal imediata, a qual, ao contrário da tradição moderna não encontra a presença identitária de um "eu" racional autoconsciente, nem simplesmente fornece dados sensíveis para um posterior processamento racional. Esse conhecimento que se dá através do corpo, não encontra a identidade de um "si mesmo" enquanto presença física ou espiritual, mas a estranheza de um "outro" irresistível que não se deixa reduzir à dimensão do corpo ou do espírito e sim de uma "terceira margem", de uma dimensão que desde sempre os extrapola, os atravessa e os constitui: a vontade (grifos do autor).

10 Carlos Drummond de Andrade. Corpo. São Paulo: Companhia das Letras, 2015, p. 21. 
Segundo Lyotard (2013, p. 25, 26), o desejo manifesta-se quando algo se lança para aquilo que lhe falta, mas essa ausência é uma ausência sentida, uma ausência presente ainda que através de símbolos. O desejo é essa força que reúne aquilo que está ausente, com aquilo que está presente. Posto isso, a saudade, como já dito, é a transubstanciação do desejo pela salvação/cura do corpo machucado pela ausência. Afinal, "todo o desejo nasce duma falta, dum estado que não nos satisfaz, portanto é sofrimento, enquanto não é satisfeito” (SCHOPENHAUER, 2001, p. 56).

Voltamos à pergunta derradeira: ausência de quê? O que nos falta? Segundo Rubem, viver num mundo ordenado pelo amor, numa ordo amoris. A religião é propriamente a imaginação/desejo e busca por esse mundo.

\section{Encontrar a ordem do amor: saudade das coisas que ainda não nasceram}

Para Alves (1975, p. 126) “...o eu não permanece fechado dentro de si. Ele deseja transbordar, fecundar a natureza com o seu sêmen, humanizá-la, engravidá-la de futuro, transformar o universo físico numa ordo amoris". É bem provável que tenha emprestado o termo “ordo amoris" de Agostinho (2000) e Scheller (2012), revelando sobretudo que:

O projeto inconsciente do ego, não importa o seu tempo e nem o seu lugar, é encontrar um mundo que possa ser amado. Há situações em que ele pode plantar jardins e colher flores. Há outras situações, entretanto, de impotência em que os objetos do seu amor só existem através da magia da imaginação e do poder milagroso da palavra. Juntam-se assim o amor, o desejo, a imaginação as mãos e os simbolos para criar um mundo que faça sentido, e esteja em harmonia com os valores do homem que o constrói, que seja espelho, espaço amigo, realização concreta dos objetos do desejo ou para fazer uso de uma terminologia que nos vem de Hegel, objetivação do Espírito (ALVES, 1981, p. 21).

Assim, segue-se a construção metafórica de Alves sobre as teias que envolvem a religião desde a ausência, perpassando a imaginação que busca criar uma ordo amoris, manifestando-se como saudade: "a imaginação é a consciência de uma ausência, a saudade daquilo que ainda não é, a declaração de amor pelas coisas que ainda não nasceram" (ALVES 1981, p. 51), "como viver a paixão infinita num mundo onde esta paixão nada mais é que um amor e um palpite, uma saudade do ausente e uma visão do que não se pode ver" (ALVES 1981, p. 63). "Mas a sua presença continua de forma mais estranha, porque ela se anuncia numa cons- 
ciência de ausência, na saudade de um bem-amado que nos deixou ou que ainda não veio" (ALVES 1981, p. 96).

De certo que as conclusões, assim postas, podem parecer apressadas, entretanto, tal caminho segue bem descrito nos livros $O$ enigma da religião, O que é religião e no Suspiro dos oprimidos. Por vezes, a religião como conceito lato é substituída pela relação entre o indivíduo e Deus, em outras, a palavra descreve as formas institucionalizadas de religião, auferindo-lhe significação pejorativa. Em todo caso, quando as variações sobre a palavra religião aparecem como condição imprescindivel da existência humana, ao fundo se revelam como saudade.

Num de seus últimos textos, O Deus que eu conheço, que trata especificamente da temática religiosa, Alves $(2013$, p. 17, 19) tenta responder a pergunta sobre sua crença ou não em Deus, ao que responde: "Se eu respondesse à pergunta dizendo que acredito em Deus, o estaria colocando no mesmo rol em que estão as montanhas, a estrela, as cebolas, uma coisa entre outras, não importando que seja a maior de todas" e à frente conclui "assim é a forma de existência dos objetos de amor - não como as montanhas, a estrela, as cebolas, mas como a saudade".

Os jogos de palavras se repetem, como variações, em seus livros. Um leitor atento descobrirá que as metáforas de Rubem são de profundidade singular. A religião para ele se manifesta em símbolos, presença da ausência. Ao mesmo tempo em que Alves (2007a, p. 57; 2013, p. 37, 126) diz que a"saudade é a presença da ausência" também diz: "O corpo de um morto: presença de uma ausência", afinal, "a morte é onde mora a saudade", é ela que nos assombra e angustia. Por conseguinte, em sua condição mais profunda, o indivíduo religioso está num velório, afinal Rubem Alves (1972, p. 11, 12) explica a partir de Feuerbach que Deus (e aqui nos referimos à ideia de religião), é a projeção humana de sua natureza existencial latente, em especial, suas potencialidades históricas não realizadas, sua ausência, aquilo que está morto nele ou que nunca chegou a nascer. Religião não é, portanto, o corpo de um morto, mas uma relação que se tem com ele, uma saudade.

Entretanto, essa saudade/religião, mostra-se ambígua, para além do temor e da angústia atemporais, ela se manifesta também em utopia e esperança futuras, e "a esperança vê o que não existe no presente. Existe só no futuro, na imaginação. A imaginação é o lugar onde as coisas que não existem, existem. Este é o mistério da alma humana: somos ajudados pelo que não existe. Quando temos esperança, o futuro se apossa dos nossos corpos" (ALVES, 2007a, p. 86).

Jardins são a metáfora de Alves $(1996$, p. 65, 67) para aquilo que nos causa nostalgia, para a eterna busca do homem por um lugar belo onde possa habitar. Afinal, "um jardim é um sonho que virou realidade, revelação da nossa verdade 
interior escondida". Assim, quando da idealização de um jardim em seu quintal pensou, "somente quem tem saudades entende os recaos dos jardins. Não chamei um paisagista porque, por competente que fosse, ele não podia ouvir os recados que eu ouvia. As saudades dele não eram as saudades minhas". Rubem vai além, coloca Cecília Meireles a declamar em seu jardim e depois conclui a metáfora:

\author{
No mistério do Sem-Fim \\ equilibra-se um planeta. \\ E, no planeta, um jardim, \\ e, no jardim, um canteiro: \\ no canteiro uma violeta, \\ e, sobre ela, o dia inteiro, \\ entre o planeta e o Sem-Fim, \\ a asa de uma borboleta.
}

Metáfora: somos a borboleta. Nosso mundo, destino, um jardim (ALVES, 1996, p. 68).

Eis a incessante busca do cristianismo pelo Reino de Deus, um jardim, o Paraíso perdido, a ordo amoris, um lugar habitado por infinita beleza. Não é a toa que infinitude pertence a Deus, porque é justamente na infinitude dos desejos humanos que ele faz morada.

\title{
4. Variações sobre a saudade
}

Gonçalo Júnior (2015, p. 345) relata inúmeras críticas recebidas por Rubem a respeito da repetitividade dos temas de seus textos, a resposta dada pelo escritor da saudade ilumina a escolha pelas considerações feitas nesse tópico: "fracassei como pianista, mas a minha cabeça funciona como a de um compositor que, havendo encontrado um tema musical pelo qual se apaixona, passa então a se dedicar a compor 'variações' sobre esse mesmo tema para que ele não termine nunca e ressuscitou o tema, transfigurando".

Dito isso, seria fácil notar a presença religiosa da saudade nos textos em que Alves trata especificamente da religião, ou seja, naqueles em que as ideias sobre o sagrado se manifestam de forma evidente. Para além disso, o que se deseja agora, é mapear nos outros textos de Rubem a possibilidade de expressões do sagrado (ou da religião), ainda que de modo camuflado. Para tanto, o que se pretende é uma leitura dos aspectos transcendentes presentes em sua obra, não daqueles que apontam para um ser sobrenatural, mas dessa transcendência imanente do 
homem que sai de si para olhar para si mesmo, proposta por Feuerbach. Busca-se sobretudo nas questões pertinentes à existência humana os rastros da saudade e o poder da imaginação.

\subsection{Teopoética}

Rubem acreditava no poder das palavras, acreditava na magia que elas evocavam, afinal, palavras são símbolos do ausente. Cervantes-Ortiz conta que em determinado encontro de lideranças religiosas, Alves chamara a atenção das pessoas sobre o papel das igrejas em relação à libertação do povo. Para ele, o problema não era somente ajudá-las, era fazer ressuscitar os corpos mortos, e isso só era possível com o poder da beleza. Uma vez que o ativismo político (como o da Teologia da Libertação de vertente católica) não poderia curar o sofrimento, "apenas a visão do paraíso, o jogo e o prazer podem fazê-lo, porque assim é possível "despertar dentro das pessoas os sonhos que jazem adormecidos em seu interior. E então ressuscitarão" (ALVES apud CERVANTES-ORTIZ, 2005, p. 158).

Queria o teólogo que a Teologia da Libertação se tornasse uma Poesia da Libertação, e assim nascia um teopoeta. Cervantes-Ortiz indica que o livro de Rubem intitulado Variações sobre a vida e a morte é paradigmático nessa nova forma de fazer teologia. Entretanto, é em O poeta, o guerreiro, o profeta e em Lições de feitiçaria que Alves demonstra de forma mais contundente o que temos visto nesse artigo. Descreve o poeta Rubem:

"Que somos nós sem o poder do que não existe?"11

Não é teologia

A teologia deseja ser ciência, um discurso sem intertícios.

Ela deseja ter os seus pássaros em gaiolas.

Em vez disso, Teo-poética, gaiolas vazias, palavras que nascem do vazio, que se dizem perante o vazio, o mar profundo (nossos olhos olham para cima, esperando a luz que se fratura através das águas inquietas...), bosques fundos (se tivermos paciência poderemos ouvir o canto do pássaro encantado que mora lá e que, no entanto, jamais foi visto por qualquer pessoa...), catedral silenciosa onde nossos pensamentos ficam leves e saltam sobre abismos (ALVES, 1990, p. 94; grifos do autor).

Sabia Rubem que as palavras precisavam enfeitiçar nosso mundo para que pudesse existir esperança. Quando a realidade não pode ser moldada pelo

11 Provavelmente parafraseando o poeta, muitas vezes citado por Rubem, Paul Valéry: "Que seria de nós sem o socorro das coisas que não existem?” 
esforço das nossas mãos, quando a técnica não pode trazer sentido para a vida, quando entendemos que o materialismo não satisfaria os desejos mais profundos de felicidade, então, a saudade nos faz ouvir o canto do pássaro encantado. Não precisamos vê-lo, nem tocá-lo. A canção traz a saudade para dentro de casa, o milagre acontece, a casa vira jardim, o passáro voa, a saudade fica, o amor cresce.

Ao comentar sobre a recepção dos textos alvesianos nos Estados Unidos, especialmente quando fala sobre o livro O poeta, o guerreiro, o profeta, Barreto Júnior (2014, p. 148), cita que Katelynn Carver ${ }^{12}$ inspira-se na leitura do texto para fazer a seguinte afirmação teopoética: "nós temos um buraco dentro de nós, mas não somos vazios. $\mathrm{Na}$ medida em que vivemos e nos engajamos em relações mais profundas - na direção da beleza - nós encontramos ressonância, as palavras mágicas que contem a sacralidade em si, os frutos mais doces e que mais profundamente nos satisfazem nos nossos jardins". Barreto Júnior comenta a citação de Katelynn subtituindo "o buraco dentro de nós" pela palavra saudade, tão cara para Rubem, "ao invés de ser um vazio, se transforma num espaço de ressonância, onde nossas palavras, insuficientes em conteúdo, nos remetem a memórias da ausência que chamamos o sagrado".

Destarte, anos depois, Rubem expressa novamente seu desejo quanto à teologia no livro Lições sobre Feitiçaria:

Gostaria que a teologia fosse isso: as palavras que tornam visíveis os sonhos e que, quando ditas, transformam o vale de ossos secos numa multidão de crianças. Daí a sugestão que faço: que a palavra teologia seja substituída pela palavra teopoesia: nada de saber, o máximo de beleza.[...] O silêncio é o espaço onde as palavras nascem e começam a se mover. Por vezes elas existem porque as dissemos. Dependem da nossa vontade de pensar, de falar, de escrever: pássaros engaiolados. Mas no silêncio ocorre uma metamorfose. As palavras se tornam selvagens, livres. Elas tomam a iniciativa. E só nos resta ver e ouvir. Elas nos vêm de outro mundo, que começa com a Palavra. Os lugares-comuns se transformam em transparências, e poder ver milhares de sentidos e caos em seu avesso. Um mundo que não haviamos visitado antes. Não, talvez o tenhamos visitado... Talvez seja o ele o lar do nosso Ser, onde nascemos. Mas ele foi esquecido quando o brilho dos reflexos nos fez esquecer nossas origens. Cada poema é um testemunho deste mundo perdido. Esta é a razão porque as palavras são criaturas das profundezas "minando ainda umidade e silêncio por entre as frias escamas” (ALVES, 2003, p. 48, 65).

12 Pesquisadora de teopoética no "Institute for Theology, Imagination and the Arts" no Reino Unido. Formada em Religião, Literatura e Cultura Harvard Divinity School e Historia e Religião pela Baldwin Wallace University. 
Novamente o mundo perdido, a nostalgia, mas também uma crítica à teologia dogmática absolutizada. A metamorfose da saudade que encarna nas palavras. E por aí seguem inúmeros textos poéticos de Rubem, variações sobre o mesmo tema, revelação de sua essência, ou melhor, de suas ausências. Uma teopoetica que nada mais faz do que declarar a impotência da beleza sobre a qual os homens dependuram o sentido da vida e da morte, mas "claro. Tudo isso é uma esperança. Mas sobre tal esperança se fazem apostas. E as vidas ficam diferentes..." (ALVES, 1982, p. 209).

E da teopoesia, Rubem caminha rumo a esse mundo de esperanças. Era preciso educar os olhos da humanidade para que pudesse enxergar a saudade. $\mathrm{O}$ teopoeta se debruça sobre a pedagogia, nasce o teopedagogo.

\subsection{Teopedagogia}

Em sua fase teológica, Rubem produziu aquilo que chamou Teologia da Libertação. Ainda que a publicação da principal obra que traz essa ideia tenha sido com o título $A$ theology of buman hope (Da Esperança, em português), a tese que deu origem ao livro levava o nome Towards a Theology of Liberation, ou seja, Por uma Teologia da Libertação, nome utilizado na versão mais recente do livro publicada no Brasil. Segundo Alves (2012, p. 51), "não me bastavam sonhos e jardins: era preciso saber que jardins poderiam se transformar em manual de jardinagem. A esperança tinha de se exprimir como política”. Pois bem, o que nos parece é que o teólogo Rubem encontrou na pedagogia as ferramentas necessárias para essa expressão política. Queria suprir as ausências da humanidade, semear sonhos e esperança. Pretensão demais? Rubem não estava só, encontrou em pessoas como Paulo Freire, Dermeval Saviani e Moacir Gadotti companheiros de jornada. A Pedagogia do Oprimido, de Freire, assemelhava-se muito às ideias de Rubem. Assim, O Suspiro dos Oprimidos, escrito pelo teólogo em 1984 como declaração de que a religião era a presença da esperança e do sentido, deu lugar à pedagogia. Foram pelo menos 19 livros e outras tantas publicações e palestras sobre o tema.

Scofano (2008, p. 135-154) escreve sobre a "Iluminação e desaprendizagem: influência do Zen-Budismo no pensamento educacional de Rubem Alves", de onde revela entre outras coisas que a posição educacional de Rubem Alves pode ser chamada de Pedagogia da Inconsciência, pois valoriza "a dimensão do prazer e dos sentidos tão desprezada pela escola que ensina ao aluno como se ele só funcionasse do 'pescoço para cima".

Doravante, Alves pensa na educação como um processo em que a imaginação é livre para dirigir o processo de construção. Segundo Nunes (2008, p. 159, 169), professor universitário e ex-aluno de Rubem, seu mestre ensinava que "a 
educação deveria ser também um exercício para a criação dos símbolos novos que nos possibilitariam renomear a realidade. Não apenas repetiríamos, mas também criaríamos". Acreditava numa educação moldada pelo princípio do prazer, por essa demanda incessante pelo "lugar da beleza adormecida", que tem a ver com a busca que habita nossos desejos mais profundos. Isso começa com uma ausência, com a saudade (sofrimento), e daí segue-se o processo de aprendizagem/criação, como Alves (2007b, p. 65-66) explica:

Como é que a criatividade se inicia? Já disse: inicialmente com um sofrimento. O sofrimento nos faz pensar. Pensamento não é uma coisa. O pensamento se faz com algo que não existe: ideias. Ideias são entidades espirituais. O espiritual é um espaço dentro do corpo onde as coisas que não existem, existem. A Pietá antes de existir como escultura, existiu no pensamento, no espírito, dentro do corpo de Michelangelo. O beijo, antes de existir como objeto de arte, existiu como espírito, dentro do corpo de Rodin. A Nona Sinfonia, antes de existir como peça musical que podemos ouvir, existiu como espírito, dentro da cabeça de Beethoven.

Desse modo, prossegue Nunes (2008, p. 160), “o que Rubem Alves quer nos alertar é para a possibilidade de um processo educativo em que as palavras possam ter, sobretudo, a função de despertar os desejos adormecidos que moram dentro do nosso corpo. O processo educativo torna-se, então, mais prezoroso, já que estaríamos mobilizando forças que nos habitam".

Para Alves (1985, p. 36), portanto, a educação deveria estar diretamente relacionada às necessidades do corpo e não à manutenção de instituições sociais opressoras, porque "a volta ao corpo implica a exigência de um assepcia geral e rigorosa em que todos os produtos da educação são colocados de quarentena, para que o corpo desafogue e desengasgue e possa tomar a iniciativa de selecionar e usar somente aquilo que lhe convier, se o quiser". Alves (200, p. 43) quer mostrar que a ciência (aquilo que almeja a educação) está muito próxima da religião, para isso usa uma frase de Whyte, complementando-a, como se segue:

"O místico crê num Deus desconhecido. O pensador e cientista crêem numa ordem desconhecida. É dificil dizer qual deles sobrepuja a outra em sua devoação não-racional"

Não estou afirmando que a religião é ciência nem que a ciência é religião. Estou, ao contrário, sugerindo que em ambos os casos os indivíduos estão em busca de ordem e que todos eles, independetemente de convicções pessoais 
concordam em que a ordem é invisivel. Esta é a razão por que Marx, que ninguém consideraria um religoso ou místico, diz que a experiência cotidiana só capta a aparência efêmera das coisas. Paulo [o apóstolo] concordaria: "As coisas que são vista são transitórias”!... E em outro lugar Marx vai dizer que, "toda ciência seria supérflua se a aparência, a forma das coisas fosse totalmente idêntica à sua natureza”.

Assim, a educação segue reproduzindo a falaciosa ideia científica de que suas construções da imaginação são cópias do real e de que o saber que ela reproduz se sobrepõe ao sabor das coisas que satisfazem os desejos. Não, Rubem não propõe o abandono de todo conhecimento histórico, apenas sugere que estes não deveriam ser gaiolas. Na verdade, parte em princípio da afirmação racionalista de Kant (apud Alves 200, p. 59), “o que os objetos são, em si mesmos, fora da maneira como nossa sensibilidade os recebe, permanece totalmente desconhecido para nós. Não conhecemos coisa alguma a não ser o nosso modeo de perceber tais objetos - um modo que nos é peculiar e não necessariamente compartilhado por todos os seres".

"O conhecimento e a ciência se iniciam quando as coisas nos provocam a fazer perguntas" (ALVES, 2011). Quais perguntas melhores do que aquelas que indagam sobre o jardim onde reside nossas saudades ontológicas?

\section{Considerações finais}

Tancara (2008, p. 191-230) parece ter chegado à conclusões parecidas sobre a questão da saudade em Rubem Alves, ainda que o caminho proposto aqui seja totalmente distinto do dele. Conclui ele "o corpo não é só biológico, transcende como utopia, sonhos desejos, imaginações, palavras; estende-se sem fim - a pele é profunda, diria Gilles Deleuze. Este corpo se converte em nostalgia ("saudade"), sonho com outro mundo, deseja estar além, ainda que não esteja seguro se existe um mais além (tem fé)".

Certamente que nunca tivemos no Brasil algo parecido com o Saudosismo português, que trazia a saudade como alma da literatura no início do século XX, carregado de nostalgia e de uma busca singular pela unidade transcendental. Foi esse movimento que tanto influenciou Fernando Pessoa e por "antropofagia" alimentou Rubem Alves. Religião para Rubem traz também esse traço medular, sobretudo porque ela nunca é encontro, mas busca, rastro, saudade.

As metáforas poderiam continuar se pensarmos na oração como cartas enviadas por alguém saudoso ao seu objeto de amor. As hierofanias como respostas alimentando a saudade. Aliás, diria Rubem, "saudade, a gente não pode 
criar, por vontade. Ela nasce, sem querer, quando o vento misterioso do Espírito sopra. E a gente sabe que é coisa do Espírito pelas coisas novas que se começa a ver. Os olhos mudam. O coração também. E é porque o coração fica diferente que os olhos começam a ver coisas que ninguém mais vê. São invisíveis. E por ver coisas invisíveis, os outros pensam que ficamos loucos" (ALVES, 1984b, p. 24). E mais, completaria Alves (2012, p. 14), "se uso a palavra Deus é como metáfora poética, nada que eu conheça, o significante que nada significa, a não ser o espaço vazio onde aparecem as minhas nostalgias e onde se coloca o dizer poético. De Deus só temos o Verbo, Poema, coisa que se diz quando a saudade dói... Isto não é jeito que eu tenha inventado". É também por isso que o velho Rubem costuma dizer que teologia não é coisa de quem acredita em Deus, mas de quem tem saudades de Deus.

Por fim, para sintetizar as ideias aqui propostas, uma paráfrase da canção de Chico Buarque: ${ }^{13}$ "religião é arrumar o quarto para o filho que ainda não nasceu".

\section{Referências}

AgOSTINHO, S. A cidade de Deus, v. II, 2000.

ALVES, R. Deus morreu, Viva Deus. In: ALVES, R.; et al. Liberdade e Fé. Rio de Janeiro: Tempo e Presença, 1972.

ALVES, R. O enigma da Religião. Petrópolis, RJ: Vozes, 1975.

ALVES, R. O que é religião, 2. ed. São Paulo: Editora Brasiliense, 1981.

ALVES, R. Variações sobre a vida e a morte: a teologia e a sua fala. São Paulo: Edições Paulinas, 1982.

ALVES, R. O suspiro dos oprimidos. São Paulo: Ed. Paulinas, 1984a.

ALVES, R. Creio na ressurreição do corpo: meditações, 4. ed. São Paulo: Paulus, 1984b.

ALVES, R. Conversas com quem gosta de ensinar, 16. ed. São Paulo, SP: Cortez: Autores Associados, 1985.

ALVES, R. O retorno e terno, 7. ed. Campinas, SP: Papirus: Speculum editora, 1996.

ALVES, R. Filosofia da ciência: introdução ao jogo e a suas regras. São Paulo: Edições Loyola, 2000.

ALVES, R. Lições de Feitiçaria. São Paulo: Edições Loyola, 2003.

ALVES, R. Perguntaram-me se acredito em Deus. São Paulo: Editora Planeta do Brasil, $2007 \mathrm{a}$.

ALVES, R. Mansamente pastam as ovelhas... 4. ed. Campinas: Papirus, 2007b.

13 Cf. música: Pedaço de mim. 
ALVES, R. O poeta, o guerreiro, o profeta. Petrópolis, RJ: Vozes, 1992.

ALVES, R. A pedagogia dos caracóis. Campinas, SP: Verus, 2011.

ALVES, R. Por uma teologia da libertação. São Paulo: Fonte Editorial, 2012.

ALVES, R. O Deus que eu conheço. Campinas, SP: Verus, 2013.

ANDRADE, C. D. Corpo. São Paulo: Companhia das Letras, 2015.

ANTUNES, A. Saudade e Profetismo em Fernando Pessoa: Elementos para uma Antropologia Filosófica. Braga: Publicações da Faculdade de Filosofia, 1983.

BARRETO JÚNIOR. R. C. Rubem Alves: o desenvolvimento de seu pensamento e a recepção do mesmo nos Estados Unidos. REFLEXUS, Ano VIII, n. 12, p. 125-154, 2014.

BOGÉA, D. B. Metafísica da vontade, metafísica do impossível: a dimensão pulsional como terceiro excluído, 2016, 292s. Tese (doutorado) - Pontifícia Universidade Católica do Rio de Janeiro, Departamento de Filosofia. Rio de Janeiro.

CERVANTES-ORTIZ, L. A teologia de Rubem Alves: Poesia, brincadeira e erotismo. Campinas: Papirus, 2005.

FEUERBACH, Ludwig. A essência do cristianismo, 4. ed. Petrópolis, RJ: Vozes, 2013.

GONÇALO JUNIOR. É uma pena não viver: Uma biografia de Rubem Alves. São Paulo: Planeta do Brasil, 2015.

LYOTARD, J. Por que filosofar? São Paulo: Parábola, 2013.

NUNES, A. V. Corpo, linguagem e educação dos sentidos no pensamento de Rubem Alves. São Paulo: Paulus, 2008.

NUNES, A. V. Entrevista com Rubem Alves. REFLEXUS, Ano VIII, n. 12, p. 215-234, 2014.

PESSOA, F. Livro do Desassossego: Composto por Bernardo Soares Ajudante de Guarda-Livros na Cidade de Lisboa. Edição de Richard Zenith. 1982; Lisboa: Assírio \& Alvim, 1998.

SCHELLER, M. Ordo Amoris. Covilhã: Universidade da Beira Interior, 2012.

SCHOPENHAUER, A. O mundo como vontade e como representação. Rio de Janeiro: Contrapontos, 2001.

SCOFANO. R. G. Iluminação e desaprendizagem: influência do Zen-Budismo no pensamento educacional de Rubem Alves. In: NUNES, A. V. (Org.). O que eles pensam de Rubem Alves e de seu humanismo na religião, na educação e na poesia, 2. ed. São Paulo: Paulus, 2008.

SILVA, A. F. Poética da existência: Rubem Alves, história de vida, tramas e narrativas, 2014, 303s. Tese (doutorado) - Universidade Estadual de Campinas, Instituto de Filosofia e Ciências Humanas. Campinas, São Paulo.

TANCARA, J. J. Florestas Profundas, mares desconhecidos: o corpo e a nostalgia no pensamento de Rubem Alves. In: NUNES, A. V. (Org.). O que eles pensam de Rubem Alves e de seu humanismo na religião, na educação e na poesia, 2. ed. São Paulo: Paulus, 2008.

Submetido em: 27-02-2017

Aceito em: 18-7-2017 